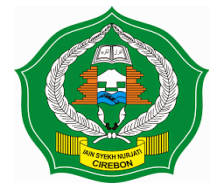

JIEM

(Journal Islamic Education of Management)

https://www.syekhnurjati.ac.id/jurnal/index.php/jiem

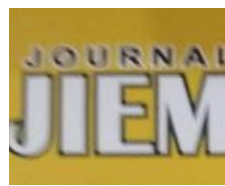

\title{
MANAJEMEN PENINGKATAN MUTU BERBASIS MADRASAH (MPMBM) di MTs Mafatihul Huda Kecamatan Depok Kabupaten Cirebon
}

\author{
Wahyono \\ Institut Agama Islam Negeri Syekh Nurjati Cirebon \\ annajiwahyono@gmail.com
}

\begin{abstract}
ABSTRAK
Madrasah adalah lembaga nonprofit yang bertujuan, bertugas, dan bertanggung jawab melaksanakan program pendidikan. Seiring dengan tuntutan zaman yang terus berubah menuju ke arah modern dan berkemajuan, dalam era persaingan yang semakin bebas dan merata seperti saat ini, lembaga pendidikan dituntut untuk dapat memberikan kualitas pendidikan yang bemutu karena lembaga pendidikan yang tidak bermutu lama kelamaan akan ditinggalkan oleh masyarakat. Bentuk dari upaya peningkatan mutu pendidikan yang dilakukan oleh pemerintah adalah dengan menetapkan kebijakan manajemen peningkatan mutu berbasis madrasah yakni dengan memberikan wewenang dari pusat kedaerah (madrasah), dimana madrasah diberi keleluasaan dan kewenangan untuk mengatur dan melaksanakan sampai pada mengevaluasi dari pendidikan yang dilaksanakan.

Penelitian ini dilakukan di MTs Mafatihul Huda dengan judul, manajemen peningkatan mutu berbasis madrasah. Sedangkan rumusan masalahnya yaitu apa konsep dasar manajemen peningkatan mutu berbasis madrasah, apa faktor pendukung dan penghambat dalam mengimplementasikan manajemen peningkatan mutu berbasis madrasah di MTs Mafatihul Huda.

Berdasarkan pada rumusan masalah tersebut, maka tujuan penelitian ini adalah untuk mengetahui, menganalisis dan mengidentifikasi konsep dasar manajemen peningkatan mutu berbasis madrasah, dan faktor pendukung dan penghambat dalam mengimplementasikan manajemen peningkatan mutu berbasis madrasah di MTs Mafatihul Huda. Dalam metode penggumpulan data melalui observasi, wawancara dan dokumentasi, dengan informannya adalah kepala MTs Mafatihul Huda, wakil kepala urusan kurikulum dan wakil kepala urusan humas. Sedangkan untuk menganalisis data menggunakan teknis analisis deskriptif kualitatif, yaitu mendeskripsikan dan mengintepretasikan data-data yang telah didapat sehingga akan mengambarkan realitas yang sebenarnya sesuai dengan fenomena yang ada.

Hasil penelitian menunjukkan bahwa manajemen peningkatan mutu pendidikan di MTs Mafatihul Huda dapat dilaksanakan dengan baik, karena madrasah telah menunjukan mutu pendidikan bagi para peserta didiknya dan sudah saatnya manajemen peningkatan mutu berbasis madrasah ini diterapkan di madrasah-madrasah untuk meningkatkan mutu pendidikan
\end{abstract}

Kata Kunci: Peningkatan Mutu Pendidikan, Manajemen Peningkatan Mutu Berbasis Madrasah 


\section{A. PEDAHULUAN}

Manajemen sering diartikan sebagai ilmu, kiat dan profesi. Dikatakan sebagai ilmu oleh Luther Gulick kerena menajemen dipandang sebagai suatu bidang pengetahuan yang secara sistematik berusaha memahami mengapa dan bagaiman orang bekerja sama. Dikatakan sebagai kiat karena manajemen mencapai sasaran melalui cara-cara dengan mengatur orang lain menjalankan tugas. Dipandang sebagai profesi kerena manajemen dilandasi oleh keahlian khusus untuk mencapai suatu prestasi manajer, dan para profesional itu dituntut kode etik tertentu (Sunhaji, 2006:8). Menurut The Liang Gie manajemen adalah segenap proses penyelenggaraan dalam setiap usaha kerjasama sekelompok manusia untuk mencapai tujuan tertentu (Suharsimi Arikunto, 2008:3).

Manajemen mencakup kegiatankegiatan untuk mencapai tujuan, dilakukan oleh individu-individu yang menyumbangkan upayanya yang terbaik melalui tindakan-tindakan yang telah ditetapkan sebelumnya. Hal tersebut meliputi pengetahuan apa yang harus mereka lakukan, menetapkan cara bagaimana melakukannya, memahami bagaiman mereka harus melakukannya dan mengukur efektifitas dari usaha-usaha mereka. Selanjutnya perlu menetapkan dan memelihara pula suatu kondisi lingkungan yang memberikan respon ekonomis, psikologis, sosial, politis dan sumbangansumbangan teknis serta pengendaliaannya. Manajemen merupakan sebuah kegiatan, pelaksanannya disebut managing dan orang yang melakukannya disebut manajer. Dalam proses manajemen terdapat fungsi-fungsi pokok yang ditampilkan oleh seorang manajer/pimpinan, yaitu : perencanaan (planning), pengorganisasian (organizing), pemimpinan (leading), dan pengawasan (controlling).
Oleh karena itu, manajemen diartikan sebagai proses merencanakan, mengorganisai, memimpin dan mengendalikan upaya organisasi dengan segala aspeknya agar tujuan organisasi tercapai secara efektif dan efisien. (http://www.geocities.com/agus_lecturer/ manajemen/pengertian_manajemen.htm).

Kata "madrasah" dalam bahasa Arab adalah bentuk kata "keterangan tempat" (zaraf makan) dari akar kata "darasa". Secara harfiah "madrasah" diartikan sebagai "tempat belajar para pelajar", atau "tempat untuk memberikan pelajaran" (Mehdi Nakosteen, 1996:66). Dari akar kata "darasa" juga bisa diturunkan kata "midras" yang mempunyai arti "buku yang dipelajari" atau "tempat belajar"; kata "al midras" juga diartikan sebagai "rumah untuk mempelajari kitab Taurat"(Abu Luwis al-Yasu'I:221). Kata "madrasah" juga ditemukan dalam bahasa Hebrew atau Aramy, dari akar kata yang sama yaitu "darasa", yang berarti "membaca dan belajar" atau "tempat duduk untuk belajar". Dari kedua bahasa tersebut, kata "madrasah" mempunyai arti yang sama: "tempat belajar".

Jika diterjemahkan ke dalam bahasa Indonesia, kata "madrasah" memiliki arti "sekolah" kendati pada mulanya kata "sekolah" itu sendiri bukan berasal dari bahasa Indonesia, melainkan dari bahasa asing, yaitu school atau scola (H.A. Malik Fadjar, 1998: iii)

Dalam prakteknya memang ada madrasah yang disamping mengajarkan ilmu-ilmu keagamaan (al ulum al diniyyah), juga mengajarkan ilmu-ilmu yang diajarkan di sekolah-sekolah umum. Selain itu ada madrasah yang hanya mengkhususkan diri pada pelajaran ilmuilmu agama, yang biasa disebut madrasah diniyyah. Kenyataan bahwa kata "madrasah" berasal dari bahasa Arab, dan tidak diterjemahkan ke dalam bahasa Indonesia, menyebabkan masyarakat lebih memahami "madrasah" sebagai lembaga 
pendidikan Islam, yakni "tempat untuk belajar agama" atau "tempat untuk memberikan pelajaran agama dan keagamaan".

Pendidikan mempunyai peranan penting dalam proses kemajuan bangsa, tanpa pendidikan kehidupan manusia terasa berkurang, sebab pendidikan merupakan kunci kemajuan, semakin baik kualitas pendidikan yang diselenggarakan oleh suatu masyarakat atau bangsa, maka akan diikuti dengan semakin baiknya kualitas masyarakat atau bangsa tersebut. Karena itu para peneliti dan pengembang pendidikan islam tiada henti-hentinya untuk membahas permasalahan tersebut. Akan tetapi dalam praktek nya pendidikan mempunyai banyak masalah.

Salah satu permasalahan pendidikan yang dihadapi oleh bangsa Indonesia adalah rendahnya mutu pendidikan pada setiap jenjang dan satuan pendidikan, khususnya pendidikan dasar dan menengah. Berbagai usaha telah dilakukan untuk meningkatkan mutu pendidikan nasional, misalnya pengembangan kurikulum nasional dan lokal, peningkatan kompetensi guru melalui pelatihan, pengadaan buku dan alat pelajaran, pengadaan dan perbaikan sarana dan prasarana pendidikan, dan peningkatan mutu manajemen sekolah. Namun demikian, berbagai indikator mutu pendidikan belum menunjukan peningkatan yang berarti. Sebagian sekolah, terutama di kota-kota, menunjukan peningkatan mutu pendidikan yang cukup menggembirakan, namun sebagian lainnya masih memprihatinkan.

Fenomena di atas diantaranya disebabkan, pertama: Karena selama ini penyelenggaraan pendidikan terlalu memusatkan pada input pendidikan dan kurang memperhatikan pada proses pendidikan. Padahal, proses pendidikan sangat menentukan output pendidikan. Kedua: penyelenggaran pendidikan nasional dilakukan secara birokratiksentralistik sehingga menempatkan sekolah sebagai penyelenggaraan pendidikan sangat tergantung pada keputusan birokrasi dan kadang-kadang kebijakan yang dikeluarkan tidak sesuai dengan kondisi sekolah setempat.

Sekolah lebih merupakan subordinasi birokrasi diatasnya sehingga mereka kehilangan kemandirian, keluwesan, motivasi, kreativitas/inisiatif untuk mengembangkan dan memajukan lembaganya termasuk peningkatan mutu pendidikan sebagai salah satu tujuan pendidikan nasional. Ketiga: peran serta warga sekolah khususnya guru dan peran serta masyarakat khususnya orang tua siswa dalam penyelenggaraan pendidikan selama ini sangat minim. Partisipasi guru dalam pengambilan keputusan sering diabaikan, partisipasi masyarakat selama ini pada umumnya sebatas pada dukungan dana. Sekolah tidak mempunyai beban untuk mempertanggung jawabkan hasil pelaksananaan pendidikan kepada masyarakat, khususnya orang tua siswa, sebagai salah satu unsur utama yang berkepentingan dengan pendidikan (stakeholder).

MBS merupakan suatu konsep yang menawarkan otonomi pada sekolah untuk menentukan kebijakan sekolah dalam rangka meningkatkan mutu, efisiensi dan pemerataan pendidikan agar dapat mengakomodasi keinginan masyarakat setempat serta menjalin kerja sama yang erat antara sekolah, masyarakat, dan pemerintah (E. Mulyasa, 2002: 11). Pada hakikatnya MBS merupakan pemberian otonomi kepada sekolah, untuk secara aktif serta mandiri mengembangkan dan melakukan berbagai program peningkatan mutu pendidikan sesuai dengan kebutuhan sekolah sendiri. MBS terlahir dengan beberapa nama yang berbeda, yaitu tata kelola berbasis sekolah (school-based governance), manajemen mandiri sekolah (school self-manegement), dan bahkan juga dikenal dengan school site management atau manajemen yang bermarkas di sekolah. Istilah-istilah tersebut memang mempunyai pengertian dengan penekanan yang sedikit berbeda. 
Namun, nama-nama tersebut memiliki roh yang sama, yakni sekolah diharapkan dapat menjadi lebih otonom dalam pelaksanaan manajemen sekolahnya, khususnya dalam penggunakaan tiga $\mathrm{M}$ nya, yaitu man, money, dan material.

Penyerahan otonomi dalam pengelolaan sekolah ini diberikan tidak lain dan tidak bukan adalah dalam rangka peningkatan mutu pendidikan. Oleh karena itu, maka Direktorat Pembinaan SMP menamakan MBS sebagai Manajemen Peningkatan Mutu Berbasis Sekolah (MPMBS).

Manajemen peningkatan mutu berbasis sekolah merupakan alternatif baru dalam pengelolaan pendidikan yang lebih menekankan kepada kemandirian dan kreatifitas sekolah. Konsep ini diperkenalkan oleh teori effective school yang lebih memfokuskan diri pada perbaikan proses pendidikan (Umaedi, 1999: 5)

Manajemen peningkatan mutu berbasis sekolah bertujuan untuk memandirikan atau memberdayakan sekolah melalui pemberian kewenangan atau otonomi kepada sekolah dan mendorong sekolah untuk melakukan pengambilan keputusan secara partisipatif (Depdiknas, 2001:4). Sekolah atau istilah lainnya adalah madrasah mempunyai kewenangan penuh dalam pengembangan organisasi sekolahnya. Pengelolaan sekolah seperti sarana pra sarana, tenaga pendidikan, pengelolaan pembelajaran adalah sbegaian dari indikator dalam menunjang mutu madrasah.

Peningkatan mutu pendidikan merupakan sasaran pembangunan di bidang pendidikan nasional dan merupakan bagian integral dari upaya peningkatan kualitas manusia secara menyeluruh. Upaya mencerdaskan kehidupan bangsa menjadi tanggung jawab pendidikan, terutama dalam mempersiapkan peserta didik menjadi subjek yang bertaqwa kepada Tuhan Yang Maha Esa, berakhlak mulia, tangguh, kreatif, mandiri, demokratis dan profesional pada bidangnya masingmasing (E. Mulyasa, 2005: 31).

Upaya peningkatan mutu pendidikan merupakan tugas bagi semua komponen yang ada di madrasah. Hal ini akan dapat dilaksanakan jika madrasah memiliki sikap dinamis, kreatif dan inovatif dalam melaksanakan peningkatan mutu pendidikan. Dalam hal ini madrasah diberikan kepercayaan untuk mengatur dan mengurus dirinya sendiri sesuai dengan kondisi lingkungan dan kebutuhan peserta didiknya.

Meskipun demikian, agar mutu pendidikan tetap terjaga dan proses peningkatan mutu tetap terkontrol maka harus ada standar yang dijadikan sebagai acuan/pedoman sebagai indikator evaluasi keberhasilan peningkatan mutu tersebut. Pemikiran ini telah mendorong munculnya pendekatan baru, yakni pengelolaan peningkatan mutu pendidikan yang dikenal dengan manajemen peningkatan mutu berbasis madrasah (MPMBM). Kebijakan Manajemen Peningkatan Mutu Berbasis Madrasah (MPMBM) merupakan salah satu bentuk desentralisasi pendidikan yang dipilih dengan tujuan untuk memandirikan sekolah dan meningkatkan mutu pendidikan. Kebijakan ini diimplementasikan dengan menerapkan manajemen yang transparan dan dengan melibatkan pihak-pihak yang berkepentingan dengan pendidikan.

Berdasarkan kenyataan-kenyataan tersebut diatas, tentu saja perlu dilakukan upaya-upaya perbaikan, salah satunya adalah melakukan reorientasi penyelenggaraan pendidikan, yaitu dari manajemen peningkatan mutu berbasis pusat menuju manajemen peningkatan mutu berbasis sekolah. MTs Mafatihul Huda adalah Madrasah atau sekolah yang terletak di Desa Kasugengan Kidul Kecamatan Depok Kabupaten Cirebon. Madrasah tersebut mengalami kemajuan dari tahun ke tahun dari mulai sarana dan prasarana, kegiatan pembelajaran, profesionalisme guru dan lain sebagainya. 
Madrasah tersebut dahulunya adalah madrasah yang sangat sederhana dan hanya mempunyai tiga ruangan saja. Dengan segala yang serba terbatas tetapi madrasah tersebut mampu melaksanakan program pendidikan.

Permasalahan yang akan diungkap dalam penelitian ini adalah sejauh mana manajemen peningkatan mutu berbasis madrasah (MPMBM) sebagai upaya untuk meningkatkan mutu pendidikan di Madrasah Tsnawiyah Mafatihul Huda. Yang mana sekolah ini mengalami kemajuan pesat dari masa ke masa. Dalam hal ini bagaimana peran MPMBM sebagai upaya dalam meningkatkan mutu sekolah atau madrasah sehingga sekolah ini dapat berjalan dengan baik dan lancar serta mengalami kemajuan yang berarti.

\section{B. Konsep Dasar Manajemen Peningkatan Mutu Berbasis Madrasah (MPMBM)}

\section{Pengertian Peningkatan Mutu Berbasis Madrasah}

Pendidikan di Indonesia telah berupaya untuk meningkatkan mutu pendidikan. Salah satu upaya yang nampak dilakukan adalah dengan menerapkan manajemen peningkatan mutu berbasis sekolah (MPMBS), yang lebih dikenal dengan istilah manajemen berbasis sekolah (MBS). Sebelum membahas lebih jauh mengenai manajemen peningkatan mutu berbasis sekolah terlebih dahulu akan dibahas mengenai mutu dan mutu pendidikan.

Banyak ahli yang mengemukakan tentang mutu, seperti yang dikemukakan oleh Edward Sallis (2006: 33) mutu adalah Sebuah filsosofis dan metodologis yang membantu institusi untuk merencanakan perubahan dan mengatur agenda dalam menghadapi tekanan-tekanan eksternal yang berlebihan. Sudarwan Danim (2007: 53) mutu mengandung makna derajat keunggulan suatu poduk atau hasil kerja, baik berupa barang dan jasa. Sedangkan dalam dunia pendidikan barang dan jasa itu bermakna dapat dilihat dan tidak dapat dilihat, tetapi dan dapat dirasakan. Sedangkan Kamus Besar Bahasa Indonesia (1991: 677) menyatakan Mutu adalah (ukuran), baik buruk suatu benda atau taraf atau derajat (kepandaian, kecerdasan, dan sebagainya) kualitas. Selanjutnya Lalu Sumayang (2003: 322) menyatakan quality (mutu) adalah tingkat dimana rancangan spesifikasi sebuah produk barang dan jasa sesuai dengan fungsi dan penggunannya, disamping itu quality adalah tingkat di mana sebuah produk barang dan jasa sesuai dengan rancangan spesifikasinya.

Berdasarkan pendapat ahli di atas, dapat disimpulan bahwa mutu (quality) adalah sebuah filsosofis dan metodologis, tentang (ukuran) dan tingkat baik buruk suatu benda, yang membantu institusi untuk merencanakan perubahan dan mengatur agenda rancangan spesifikasi sebuah produk barang dan jasa sesuai dengan fungsi dan penggunannya agenda dalam menghadapi tekanan-tekanan eksternal yang berlebihan.

Peningkatan mutu pada hakikatnya merupakan upaya perubahan. Oleh karena itu, proses perubahan dalam peningkatan mutu pendidikan adalah suatu keharusan dan keniscayaan. Tanpa ada proses perubahan tidak ada mutu pendidikan. Mutu pendidikan adalah hasil proses perubahan. Dengan demikian, proses prubahan menjadi sangat penting dalam upaya meningkatkan mutu pendidikan.

Perubahan dalam rangka peningkatan mutu pendidikan harus dilakukan secara kompereshif, meliputi berbagai komponen yang berpengaruh dan determinan terhadap peningkatan mutu. Komponen-kompnen itu seperti sisiwa peserta didik, tenaga pendidikan, pengelola pembina, komite sekolah, sarana prasarana, media, sumber belajar, kurikulum, metode dan teknik, manajemen sekolah, proses pembelajaran, dan lingkungan sekolah. Hal demikian karena pendidikan merupakan suatu sistem yang komponen-komponennya saling 
berpengaruh satu dengan yang lainnya dalam mencapai suatu tujuan. Oleh karena itu, perubahan yang dilakukan secara parsial tidak akan efektif bagi peningkatan mutu pendidikan.

Tantangan dunia pendidikan kita saat ini semakin berat dan kompleks. Mutu pendidikan kita dalam berbagai apek masih rendah bila dibandingkan dengan mutu pendidikan negara-negara lain di Asia, terlebih di dunia. Ini menunjukkan bahwa SDM pendidikan kita masih lemah sehingga masalah ini berdampak pula pada out pendidikan berupa SDM yang lemah pula. Oleh karena itu, untuk menjawab tantangan tersebuut perlu dibangun SDM pendidikan yang handal dan kompetitif, baik pada level penentu kebijakan, perencana, maupun pelaksana pendidikan di lembaga-lembaga pendidikan.

Dalam pandangan Zamroni (2007: 2) dikatakan bahwa peningkatan mutu sekolah adalah suatu proses yang sistematis yang terus menerus meningkatkan kualitas proses belajar mengajar dan faktor-faktor yang berkaitan dengan itu, dengan tujuan agar menjadi target sekolah dapat dicapai dengan lebih efektif dan efisien. Peningkatan mutu berkaitan dengan target yang harus dicapai, proses untuk mencapai dan faktorfaktor yang terkait. Dalam peningkatan mutu ada dua aspek yang perlu mendapat perhatian, yakni aspek kualitas hasil dan aspek proses mencapai hasil tersebut. Menurut teori ini, mutu sekolah ditentukan oleh tiga variabel, yakni kultur sekolah, proses belajar mengajar, dan realitas sekolah. Kultur sekolah merupakan nilainilai, kebiasaan-kebiasaan, upacaraupacara, slogan-slogan, dan berbagai perilaku yang telah lama terbentuk di sekolah dan diteruskan dari satu angkatan ke angkatan berikutnya, baik secara sadar maupun tidak. Kultur ini diyakini mempengaruhi perilaku seluruh komponen sekolah, yaitu: guru, kepala sekolah, staf administrasi, siswa, dan juga orang tua siswa. Kultur yang kondusif bagi peningkatan mutu akan mendorong perilaku warga kearah peningkatan mutu sekolah, sebaliknya kultur yang tidak kondusif akan menghambat upaya menuju peningkatan mutu sekolah.

Selanjutnya untuk meningkatkan mutu sekolah seperti yang disarankan oleh Sudarwan Danim (2007: 56), yaitu dengan melibatkan lima faktor yang dominan yaitu:

1. Kepemimpinan Kepala sekolah; kepala sekolah harus memiliki dan memahami visi kerja secara jelas, mampu dan mau bekerja keras, mempunyai dorongan kerja yang tinggi, tekun dan tabah dalam bekerja, memberikan layanan yang optimal, dan disiplin kerja yang kuat

2. Siswa; pendekatan yang harus dilakukan adalah "anak sebagai pusat “ sehingga kompetensi dan kemampuan siswa dapat digali sehingga sekolah dapat menginventarisir kekuatan yang ada pada siswa

3. Guru; pelibatan guru secara maksimal , dengan meningkatkan kopmetensi dan profesi kerja guru dalam kegiatan seminar, MGMP, lokakarya serta pelatihan sehingga hasil dari kegiatan tersebut diterapkan disekolah

4. Kurikulum; adanya kurikulum yang ajeg / tetap tetapi dinamis, dapat memungkinkan dan memudahkan standar mutu yang diharapkan sehingga goals (tujuan) dapat dicapai secara maksimal

5. Jaringan Kerjasama; jaringan kerjasama tidak hanya terbatas pada lingkungan sekolah dan masyarakat semata (orang tua dan masyarakat) tetapi dengan organisasi lain, seperti perusahaan / instansi sehingga output dari sekolah dapat terserap didalam dunia kerja.

Berdasarkan pendapat diatas, perubahan paradigma harus dilakukan secara bersama-sama antara pimpinan dan karyawan sehingga mereka mempunyai langkah dan strategi yang sama yaitu 
menciptakan mutu dilingkungan kerja khususnya lingkungan kerja pendidikan. Pimpinan dan karyawan harus menjadi satu tim yang utuh (teamwork) yangn saling membutuhkan dan saling mengisi kekurangan yang ada sehingga target (goals) akan tercipta dengan baik.

Pendidikan yang bermutu adalah pendidikan yang menghasilkan lulusan yang memiliki kemampuan atau kompetensi. Baik kompetensi akademik maupun kompetensi kejuruan, yang dilandasi oleh kompetensi personal dan sosial, yang secara menyeluruh disebut sebagai kecakapan hidup (life skill). Untuk dapat meningkatkan mutu pendidikan, madrasah harus dapat melaksanakan pengelolaan yang didasarkan pada peningkatan mutu pendidikan madrasah (Prim Masrokan Mutohar, 2013). Aplikasi manajemen peningkatan mutu pendidikan terhadap sekolah maupun madrasah didasarkan atas pemikiran bahwa para administrator dan manager pendidikan perlu menemukan kerangka kerja yang muncul dari dalam lembaga.

Salah satu konsep yang ditawarkan untuk meningkatkan potensi madrasah ialah dengan menerapkan Manajemen Peningkatan Mutu Berbasis Madrasah/Sekolah (MPMBM/S) atau yang lebih dikenal dengan Manajemen Pendidikan Sekolah (MPS). Sehingga setiap institusi pendidikan lebih leluasa dalam mengolah dan mengembangkan potensi yang dimiliki. Manajemen Peningkatan Mutu Berbasis Madrasah (MPMBM) merupakan istilah lain dari MPMBS (Manajemen Peningkatan Mutu Berbasis Sekolah), yang memiliki konsep dasar sebagai berikut: pertama, pengambilan keputusan pendidikan dilaksanakan pada level sekolah, namun tentu saja tetap dalam koridor pendidikan yang secara umum ditetapkan secara nasional. Kedua, pengambilan keputusan dilakukan secara partisipatif bersama stakeholder sekolah. Dalam MPMBM, sekolah memiliki kewenangan menentukan dalam berbagai kebijakan operasional pendidikan yang diyakini sesuai dengan kebutuhan dan karateristik anak didik. Paling tidak ada sembilan bidang yang menjadi "wilayah kewenangan" tersebut, yaitu: (1) perencanaan dan evaluasi program sekolah, (2) pengelolaan kurikulum, (3) pengelolaan proses pembelajaran, (4) pengelolaan ketenagaan, (5) pengelolaan peralatan dan fasilitas, (6) pengelolaan keuangan, (7) pelayanan kesiswaan, (8) hubungan sekolah dan masyarakat, dan (9) pengelolaan iklim sekolah.

Pakar pendidikan mendefinisikan Manajemen Pendidikan Sekolah (MPS) diantaranya Mulyana menjelaskan bahwa:

"Manajemen berbasis sekolah merupakan salah satu upaya pemerintah untuk mencapai keunggulan masyarakat bangsa dalam penguasaan ilmu dan teknologi yang ditunjukkan dengan pernyataan politik dalam Garis-garis Besar Haluan Negara (GBHN)"(Mulyasa, 2007: 11).

Myers dan Stonchill mendefinisikan Manajemen Pendidikan Sekolah (MPS) dengan:

"Manajemen berbasis sekolah adalah strategi untuk memperbaiki pendidikan dengan mntransfer otoritas pengambilan keputusan secara signifikan dari pemerintah dan daerah ke sekolah-sekolah secara individual."

Adapun Nurkholis mengemukakan:

"Manajemen berbasis sekolah adalah alternative sekolah sebagai hasil dari desentralisasi Pendidikan (Nurkholis, 2003: 3)

Berdasarkan pernyataanpernyataan tersebut di atas, yang dimaksud Manajemen Peningkatan Mutu Berbasis Madrasah/Sekolah (MPMBM/S) dalam penelitian ini yaitu model manajemen yang memberikan otonomi lebih besar kepada sekolah, memberikan 
fleksibilitas/keluwesan lebih besar kepada sekolah atau madrasahuntuk mengelola sumber daya sekolah dan mendorong sekolah untuk melakukan pengambilan keputusan secara partisipatif untuk memenuhi kebutuhan mutu sekolah atau untuk mencapai tujuan mutu sekolah dalam kerangka pendidikan nasional.

Dengan pengertian di atas, maka sekolah memiliki kewenangan (kemandirian) lebih besar dalam mengelola sekolahnya (menetapkan sasaran peningkatan mutu, menyusun rencana peningkatan mutu, melaksanakan rencana peningkatan mutu, dan melakukan evaluasi pelaksanaan peningkatan mutu), memiliki fleksibilitas pengelolaan sumberdaya sekolah, dan memiliki partisipasi yang lebih besar dari kelompokkelompok yang berkepentingan dengan sekolah. Dengan kepemilikan ketiga hal ini, maka sekolah merupakan unit utama pengelolaan proses pendidikan, sedang unit-unit diatasnya (Dinas Pendidikan Kabupaten/Kota, Dinas Pendidikan Propinsi, dan Departemen Pendidikan Nasional) akan merupakan unit pendukung dan pelayan Sekolah, khususnya dalam pengelolaan peningkatan mutu. Sekolah yang mandiri atau berdaya memiliki ciriciri sebagai berikut (Artikel pendidikan: konsep dasar MPMBM, (www.dikdasmen.depdiknas.go.id,10-13)

1) Tingkat kemandirian tinggi/tingkat ketergantungan rendah

2) Bersifat adaptif dan antisipatif/proaktif sekaligus; memiliki jiwa kewirausahaan tinggi (ulet, inovatif, gigih, berani mengambil resiko, dan sebagainya)

3) Bertanggungjawab terhadap kinerja sekolah

4) Memiliki kontrol yang kuat terhadap input manajemen dan sumber dayanya

5) Memiliki control yang kuat terhadap kondisi kerja

6) Komitmen yang tinggi pada dirinya dan
7) Prestasi merupakan acuan bagi penilaiannya.

Secara umum, paparan di atas telah memberikan gambaran tentang konsep dan dasar sekolah berbasis otonomi sekolah. Selanjutnya adalah upaya yang dilakukan oleh pihak sekolah untuk melakukan upaya peningkatan mutu sekolah. Sekolah yang telah diberi kewenangan penuh untuk memformulasikan ukuran keberhasilan dan kualitas pendidikannya pun akhirnya memiliki ketergantungan penuh terhadap budaya organisasi yang dipimpin oleh kepala sekolah dan pihak-pihak lain yang berkepentingan terhadap sekolah. Secara alamiah proses hidup mati organisasi selalu tergantung kepada kemampuan organisasi memenuhi harapan dan kebutuhan stakeholdernya (Listyo Prabowo, 2008: 2). Pemenuhan terhadap kebutuhan stakeholder menjadi langkah yang wajib ditempuh untuk meningkatkan kualitas pendidikan sekolah. Proses selanjutnya adalah upaya untuk memformulasikan visi, misi, dan tujuan sekolah. Setelah formulasi visi, misi, dan tujuan pun tercapai kemudia dilakukan perencanaan strategis untuk mencapai visi, misi dan tujuan tersebut. Perencanaan strategis itu pun dituangkan ke dalam rencana program-program dan rencana kegiatan. Setelah proses tersebut selesai dilaksakan proses selanjutnya adalah mengkalkulasi kebutuhan finansial untuk membiayai semua program sekolah tersebut. Setelah proses tersebut diatas, kemudian memetakan letak demografis sekolah dan stakeholder potensial yang mungkin didapatkan sekolah. Hal itu diperlukan untuk mendukung proses pemenuhan kebutuhan finansial dan dukungan moral secara penuh dari para stakeholder pada program-program sekolah.

Esensi MPMBS adalah otonomi sekolah plus fleksibilitas plus partisipasi untuk mencapai sasaran mutu sekolah. Otonomi dapat diartikan sebagai kewenangan/kemandirian yaitu kemandirian dalam mengatur dan 
mengurus dirinya sendiri, dan merdeka/tidak tergantung. Fleksibilitas dapat diartikan sebagai keluwesankeluwesan yang diberikan kepada sekolah untuk mengelola, memanfaatkan dan memberdayakan sumberdaya sekolah seoptimal mungkin untuk meningkatkan mutu sekolah. Peningkatan partisipasi yang dimaksud adalah penciptaan lingkungan yang terbuka dan demokratik, dimana warga sekolah (guru, siswa, karyawan) dan masyarakat (orang tua siswa, tokoh masyarakat, ilmuwan, usahawan) didorong untuk terlibat secara langsung dalam penyelenggaraan pendidikan, mulai dari pengambilan keputusan, pelaksanaan, dan evaluasi pendidikan yang diharapkan dapat meningkatkan mutu pendidikan.

MPMBS merupakan bagian dari manajemen berbasis sekolah (MBS). Jika MBS bertujuan untuk meningkatkan semua kinerja sekolah (efektivitas, kualitas/mutu, efisiensi, inovasi, relevansi, dan pemerataan serta akses pendidikan), maka MPMBS lebih difokuskan pada peningkatan mutu. Hal ini didasari oleh kenyataan bahwa mutu pendidikan nasional kita saat ini sangat memprihatinkan sehingga memerlukan perhatian yang lebih serius.

\section{Karakteristik \\ Peningkatan Mutu Berbasis Madrasah/Sekolah (MPMBM/S)}

Sekolah atau madrasah ingin sukses dalam menerapkan MPMBM, maka sejumlah karakteristik ini perlu dimiliki. Karakteristik Manajemen Peningkatan Mutu Berbasis Madrasah/Sekolah (MPMBM/S) memuat secara inklusif elemen-elemen sekolah yang efektif, yang dikategorikan menjadi input, proses, dan output. Selanjutnya yang dikategorikan menjadi input, output dan proses (Sofan Amri, 2013: 299-303) yaitu:

\section{Input}

Input pendidikan terdiri dari:

a. Memiliki kebijakan, tujuan, dan sasaran mutu yang jelas b. Sumber daya tersedia dan siap

c. Staf kompeten dan berdedikasi tinggi

d. Memiliki harapan prestasi yang tinggi

e. Fokus pada peserta didik

f. Input manajemen

\section{Proses}

Sekolah yang efektif pada umumnya memiliki sejumlah karakteristik proses sebagai berikut:

a. Proses belajar mengajar yang efektivitasnya tinggi

b. Kepemimpinan sekolah yang kuat

c. Lingkungan sekolah yang aman dan tertib

d. Pengelolaan tenaga kependidikan yang efektif

e. Sekolah memiliki budaya mutu

f. Sekolah memiliki teamwork yang kompak, cerdas, dan dinamis

g. Sekolah memiliki kewenangan (kemandirian)

h. Partisipasi yang tinggi dari warga sekolah dan masyarakat

$i$. Sekolah memiliki keterbukaan (transparansi) manajemen

j. Sekolah memiliki kemauan untuk berubah

k. Sekolah melakukan evaluasi dan perbaikan secara berkelanjutan

l. Sekolah responsif dan antisipasif terhadap kebutuhan

m. Komunikasi yang baik, dan

n. Memiliki akuntabilitas

\section{Output}

Output pendidikan adalah kinerja sekolah. Kinerja sekolah dapat diukur dari kualitasnya, efektivitasnya, produktifitasnya, efesiensinya, inovasinya, kualitas kehidupan kerjanya, dan moral kerjanya. Output sekolah dapat dikatakan berkualitas dan bermutu tinggi apabila prestasi pencapaian siswa menunjukan pencapaian yang tinggi dalam bidang:

1) Prestasi akademik, berupa nilai ujian semester, ujian nasional, karya ilmiah, dan lomba akademik

2) Prestasi non akademik, berupa kualitas iman dan takwa, kejujuran, 
kesopanan, olahraga, kesenian, keterampilan, dan kegiatankegiatan ekstrakulikuler lainnya

\section{Landasan Hukum}

Otonomisasi sekolah yang dipayungi oleh Manajemen Pendidikan Berbasis Madrasah/ Sekolah (MBMPM/S) diamanatkan oleh bebarapa dasar hukum di antaranya (http://jurnalsdm.blogspot.com/2010/03/manajemenpeningkatan-mutu-berbasis.html) :

1. Undang-undang nomor 25 tahun 2000 tentang Program Pembangunan Nasional (Propenas) secara jelas menyebutkan Manajemen Berbasis Sekolah (MBS) merupakan pola pembinaan sekolah/lembaga pendidikan di Indonesia

2. Undang-Undang Sistem Pendidikan Nasional Nomor 20 Tahun 2003 pasal (51) ayat (1) secara tegas dinyatakan "Pengelolaan satuan pendidikan anak usia dini, pendidikan dasar, dan pendidikan menengah dilaksanakan' berdasarkan Standar Pelayanan Minimal (SPM) dengan prinsip manajemen berbasis sekolah/madrasah"

3. Undang-Undang Nomor 32 Tahun 2004 tentang pemerintahan daerah, bahwa secara langsung atau tidak, daerah dan sekolah memiliki kewenangan untuk menyelenggarakan pendidikan secara otonomi dan bertanggung jawab

4. Undang-Undang Nomor 9 Tahun 2009 pasal (3) Badan Hukum Pendidikan menyatakan bahwa Badan Hukum Pendidikan bertujuan memajukan pendidikan nasional dengan menerapkan Manajemen Berbasis Sekolah/Madrasaah pada jenjang pendidikan dasar dan menengah dan otonomisasi perguruan tinggi pada jenjang pendidikan tinggi

5. Peraturan Menteri Agama Republik Indonesia Nomor 90 Tahun 2013 pasal (41) ayat (1) Pengelolaan madrasah dilakukan dengan menerapkan manajemen berbasis madrasah yang dilaksanakan dengan prinsip keadilan, kemandirian, kemitraan dan partisipasi, nirlabam efisiensi, efektivitas, dan akuntabilitas.

4. Prinsip-prinsip

Peningkatan Madrasah/Sekolah (MPMBM/S)

Prinsip-prinsip yang perlu diperhatiakan dalam melaksanakan manajamen peningkatan mutu berbasis madarash (Sofan Amri, 2013: 298) adalah:

1. Komitmen, kepala madrasah dan warga madrasah harus mempunyai komitmen yang kuat dalam upaya penyelenggaraan semua kegiatan madrasah

2. Kesiapan, semua warga madarsah harus siap fisik dan mental

3. Keterlibatan, pendidikan yang efektif melibatkan semua pihak dalam mendidik anak

4. Kelembagaan, madrasah sebagai lembaga adalah unit terpenting bagi pendidikan yang efektif

5. Keputusan, segala keputusan madrasah dibuat oleh pihak yang benar-benar mengerti pendidikan

6. Kesadaran, guru-guru harus memiliki kesadaran untuk membantu dalam pembuatan keputusan program pendidikan dan kurikulum

7. Kemandirian, madrasah harus diberi otonomi sehingga memiliki kemandirian dalam membuat keputusan pengalokasian dana

8. Ketahanan, perubahan akan bertahan lebih lama apabila melibatkan stakeholders madarsah.

\section{Tujuan Manajemen Peningkatan Mutu Berbasis Madrasah/Sekolah (MPMBM/S)}

Pada dasarnya MPMBM/S bertujuan untuk memandirikan dan memberdayakan sekolah melalui pemberian kewenangan (otonomi) kepada madrasah dan mendorong madrasah untuk melakukan pengambilan keputusan secara partisipasif. Lebih rincinya manajemen peningkatan mutu berbasis madarasah bertujuan untuk (Sofan Amri, 2013: 304): 
1. Meningkatkan mutu pendidikan melalui kemandirian dan inisiatif madrasah dalam mengelola dan memberdayakan sumber daya yang tersedia.

2. Meningkatkan kepedulian warga sekolah dan masyarakat dalam pennyelenggaraan pendidikan melaluipengambilan keputusan bersama (partisipasif).

3. Meningkatkan tanggung jawab sekolah kepada orang tua, masyarakat, dan pemerintah tentang mutu seolahnya.

4. Meningkatkan kompetisi yang sehat antar sekolah tentang mutu pendidikan yang akan dicapai.

\section{Faktor yang Mendorong Penerapan MPMBM}

MPMBM diterapakan karena beberapa faktor diantaranya adalah sebagai berikut (http://www.ssep.net/director.html):

1. Sekolah lebih mengetahui kekuatan, kelemahan, peluang, ancaman bagi dirinya sehingga dapat mengoptimalkan pemanfaatan sumber daya yang tersedia untuk memajukan sekolahnya

2. Sekolah lebih mengetahui kebutuhan, khususnya input pendidikan yang akan dikembangkan dan didayagunakan dalam proses pendidikan sesuai dengan tingkat perkembangan dan kebutuhan peserta didik

3. Pengambilan keputusan yang dilakukan oleh sekolah lebih cocok untuk memenuhi kebutuhan sekolah karena pihak sekolahlah yang paling tahu apa yang terbaik bagi sekolahnya

4. Keterlibatan warga sekolah dan masyarakat dalam pengambilan keputusan sekolah menciptakan transparansi dan demokrasi yang sehat

5. Sekolah dapat bertanggung jawab tentang mutu pendidikan masingmasing kepada pemerintah, orang tua peserta didik dan masyarakat pada umumnya, sehingga akan berupaya semaksimal mungkin untuk melaksanakan dna mencapai sasaran mutu pendidikna yang telah direncanakan.

\section{Strategi Implementasi Ditingkat Madrasah}

Strategi Implementasi manajemen berbasis sekolah menurut Nurkholis:

"Strategi Implementasi manajemen berbasis sekolah meliputi otonomi sekolah, peran serta masyarakat secara aktif dalam hal pembiayaan dan pengambilan keputusan berkaitan dengan pendidikan, kepemimpinan sekolah yang kuat sehingga mampu mendayagunakan setiap sumber daya sekolah secara efektif, proses pengambilan keputusan secara demokratis dalam kehidupan dewan sekolah yang aktif, pemahaman peran serta tanggungjawab semua pihak secara sungguh-sungguh, rambu-rambu dari dinas pendidikan setempat untuk mendorong proses pendidikan, transparansi dan akuntabilitas dari sekolah dalam laporan pertanggungjawaban setiap tahun, pennerapan manajemen berbasis sekolah pada penncapaian kinerja sekolah dan peningkatan prestasi belajar siswa, serta implementasi diawali sosialisasi dari konsep manajemen berbasis sekolah." (Nurkholis, op.chit:132-135)

Peningkatan mutu pendidikan di sekolah perlu didukung kemampuan manajerial para kepala sekolah. Menurut Direktorat Jenderal Pendidikan Dasar dan Menengah (2000) penerapan MPMBM/S di sekolah itu melalui tahapan kegiatan sebagai berikut (Bafadal, 2006: 90-91) :

1. Penyusunan basis data dan profil sekolah lebih presentatif, akurat, valid dan secara sistematis menyangkut berbagai aspek akademis, administratif (siswa, guru, dan staf) dan keuangan. 
2. Melakukan evaluasi diri (self assessment) untuk menganalisa kekuatan dan kelemahan mengenai sumber daya sekolah, personil sekolah, kinerja dalam mengembangkan dan mencapai target kurikulum dan hasil-hasil yang dicapai siswa berkaitan dengan aspek-aspek intelektual dan keterampilan, maupun aspek lainnya.

3. Mengidentifikasi kebutuhan sekolah, dan merumuskan visi, misi, dan tujuan dalam rangka menyajikan pendidikan yang berkualitas bagi siswanya sesuai dengan konsep pembangunan nasional yang akan dicapai.

4. Merencanakan dan menyusun program kerja Jangka panjang dan jangka pendek sesuai dengan visi misi dan tujuan yang telah dirumuskan, yang diprioritaskan pada peningkatan mutu pendidikan.

5. Mengimplementasikan program kerja.

6. Melakukan monitoring dan evaluasi untuk menyakinkan apakah program yang telah direncanakan dapat dilkasanakan sesuai tujuan, apakah tujuan telah tercapai, dan sejauh mana pencapaiannya.

7. Menyusun program lanjutan (untuk tahun berikutnya) atas dasar hasil monitoring dan evaluasi.

Adapun tahap-tahap pelaksanaan Manajemen Peningkatan Mutu Berbasis Madrasah/Sekolah (MPMBM/S) adalah sebagai berikut (Sofan Amri, 2013: 304307:

1. Melakukan Sosialisasi

2. Mengidentifikasi Tantangan Nyata Sekolah

3. Merumuskan Tujuan Situasional/Tujuan Jangka Pendek (Sasaran) Sekolah

4. Melakukan Analisis SWOT
5. Menyusun Rencana dan Program Peningkatan Mutu

6. Melaksanakan Rencana Peningkatan Mutu

7. Melakukan Evaluasi Pelaksanaan

8. Merumuskan Sasaran Mutu Baru

8. Analisis Kelebihan dan Kekurangan MPMBM/S mempunyai kelebihan, yaitu:

1. Memungkinkan orang-orang yang kompeten di sekolah untuk mengambil keputusan yang akan meningkatkan pembelajaran

2. Memberi peluang bagi seluruh anggota sekolah untuk terlibat dalam pengambilan keputusan penting

3. Mendorong munculnya kreativitas dalam merancang bangun program pembelajaran

4. Mengarahkan kembali sumber daya yang tersedia untuk mendukung tujuan yang dikembangkan di setiap sekolah

5. Menghasilkan rencana anggaran yang lebih realistik ketika orang tua dan guru makin menyadari keadaan keuangan sekolah, batasan pengeluaran, dan biaya programprogram sekolah

6. Meningkatkan motivasi guru dan mengembangkan kepemimpinan baru di semua level.

Dengan kelebihan-kelebihan di atas tentunya memajemen ini juga mempunyai sisi kelemahan dalam pelaksanaannya, yang diantaranya adalah sebagai berikut:

1. Penerapan MPMBM/S juga mengalami masalah, khususnya di daerah yang pedesaan atau daerah yang terpencil (remote areas). Banyak orangtua siswa dan masyarakat di pedesaan yang tidak mau terlibat dalam kegiatan Komite Sekolah. Masalahnya ternyata bukan hanya karena masalah kapasitasnya yang rendah, tetapi lebih karena budaya yang hanya menyerahkan bulat-bulat 
urusan pendidikan kepada pihak sekolah. Bahkan, dalam beberapa kasus, penerapan MBS lebih sebagai instrumen politik untuk membangun kekuasaan. Dengan MBS, seakan-akan pemerintah telah memberikan otonomi kepada sekolah, padahal sesungguhnya sekolah dan masyarakat belum siap untuk menerima semua itu

2. Penerapan MBS di sekolah di banyak negara berkembang, walaupun bagaimana, sering tidak memperoleh dukungan yang memadai dari pihak penguasa lokal maupun dari masyarakat. Pemerintah daerah yang lemah tidak dapat diharapkan untuk mendukung pelaksanaan prinsip manajemen modern (demokratis, transparan, dan akuntabel)

3. Sikap mental para pengelola pendidikan, baik yang memimpin maupun yang dipimpin. Yang dipimpin bergerak karena "perintah" atasan, bukan karena rasa tanggung jawab. Yang memimpin sebaliknya, terkadang tidak memberi kepercayaan, tidak memberi kebebasan berinisiatif, mendelegasikan wewenang

4. Kepala sekolahnya masih cenderung manampilkan gaya kepemimpinan otoriter, hal ini karena lemahnya kemandirian sekolah akibat pembinaan pemerintah yang sangat sentralistik. Birokratik, formalistik, konformistik, uniformistik dan mekanistik. Pembinaan yang demikian ini tidak memberdayakan potensi sekolah

5. Dalam manajemen mutu pendidikan adalah terkadang tidak adanya tindak lanjut dari evaluasi program. Hampir semua program dimonitor dan dievaluasi dengan baik, Namun tindak lanjutnya tidak dilaksanakan. pelaksanaan

Akibatnya pendidikan selanjutnya tidak ditandai oleh peningkatan mutu.

\section{HASIL PENELITIAN DAN PEMBAHASAN}

1. Manajemen Peningkatan Mutu Berbasis Madrasah di MTs Mafatihul Huda

Manajemen peningkatan mutu berbasis madrasah sebagai model manajemen yang memberikan otonomi lebih besar kepada madrasah, memberikan keluwesan/fleksibelitas kepada madrasah untuk mengelola sumber daya madrasah dalam upaya peningkatan mutu pendidikan serta meningkatkan partisipasi warga madrasah dan masyarakat untuk memenuhi kebutuhan mutu madrasah dalam kerangka pendidikan nasional. Pemberian otonomi yang lebih besar kepada madrasah, memberikan kewenangan yang lebih dalam mengelola dan mendesain guna untuk mengembangkan program-program serta potensi yang dimiliki madrasah secara maksimal, hal ini karena kondisi madrasah tidaklah sama dengan lembaga pendidikan yang lain.

$\begin{array}{cc}\text { Dari hasil observasi } & \text { peneliti } \\ \text { dilapangan menunjukkan } & \text { bahwa }\end{array}$ aktualisasi manajemen peningkatan mutu berbasis madrasah di MTs Mafatihul Huda sudah bagus, dimana ini didasarkan pada pengamatan peneliti terhadap kondisi dan realitas yang ada, begitu juga dengan hasil wawancara peneliti dengan kepala madrasah dan para wakil kepala madrasah yang menyampaikan bahwa manajemen peningkatan mutu berbasis madrasah sebagai kebijakan nasional. MTs Mafatihul Huda telah melaksanakan konsep MPMBM, sebab pada dasarnya sejak awal keberadaannya madrasah berangkat dari, untuk dan oleh masyarakat, sehingga sampai pada tumbuh kembangnya pun tergantung pada masyarakat. Inilah yang menjadi nilai plus bagi madrasah dalam merealiasikan MPMBM, dimana madrasah dituntut untuk lebih mandiri dalam mengelola lembaganya. 
Bukan hal yang rumit dalam merealisasikan MPMBM ini untuk MTs Mafatihul Huda, bahkan dengan diberlakukannya MPMBM sebagai sebuah kebijakan nasional merupakan angin segar bagi mereka untuk terus mengembangkan dan lebih meningkatkan mutu pendidikan seperti yang telah mereka kelola selama ini, lebih-lebih MPMBM ini merupakan kebijakan nasional yang salah satu tujuanya untuk meningkatkan mutu pendidikan.

Maka dalam upaya peningkatan mutu pendidikan, MTs Mafatihul Huda melakukan analisis terlebih dahulu sebelum merumuskan program yang akan dilakukan untuk mengetahui kebutuhan masyarakat dan tantangan yang akan dihadapi, karena harapan dari madrasah out put yang nantinya dihasilkan oleh MTs Mafatihul Huda bisa bersaing dengan lulusan tingkat SMP yang lain dan mampu memberikan pengaruh pada lingkungan dimanapun mereka berada.

\section{a. Tahap-tahap Perencanaan \\ 1) Analisis situasi}

Sebelum penyusunan rencana peningakatan mutu pendidikan, hal pertama yang harus dilakukan adalah analisis situasi madrasah untuk mengetahui tantangan (ketidaksesuaian antara keadaan sekarang dengan yang diharapkan). Besar kecilnya ketidaksesuaian antara situasi sasaran sekarang dengan situasi yang diharapan menunjukkan bersar kecilnya tantangan. Kegiatan analisis ini dilakukan oleh kepala madrasah bersama-sama dengan para waka dan staff madrasah setelah melakukan identifikasi fungsi-fungsi yang diperlukan untuk mencapai sasaran peningkatan mutu pendidikan. Berdasarkan hasil analisis tersebut, madrasah merumuskan programprogram yang mengacu pada visi dan misi madrasah, karena visi misi madrasah merupakan targetan yang akan dicapai dalam satu periode akademik, dimana dalam pelaksanaanya tercermin dalam bentuk program-program madrasah.
Berkenaan dengan proses perencanaan peningkatan mutu pendidikan di madrasah berikut hasil wawancara peneliti dengan kepala madrasah yang berkenaan dengan perencaan peningkatan mutu pendidikan:

\section{2) Merumuskan Sasaran}

Sasaran yang akan dicapai tercermin dalam visi madrasah, kerenanya dalam merumuskan sasaran berpedoman pada visi madrasah. Visi adalah gambaran yang menjadi acuan bagi madrasah dan digunakan untuk merumuskan misi madrasah. Dengan kata lain, visi adalah pandangan jauh kedepan karena madrasah akan dibawa atau bagaimana madrasah yang diinginkan dimasa depan, gambaran seperti itu akan selalu diwarnai peluang dan tantangan. Maka dari itu dalam perumusan program tidak lepas dari visi madrasah sebagaimana Visi dan Misi MTs Mafatihul Huda.

Dari sini kemudian diterjemahkan dalam bentuk program, yang telah dirakerkan bersama, karena programprogram itu tidak mungkin dilaksanakan hanya satu bagian saja, akan tetapi saling menguatkan, mendukung, dan bekerjasama satu sama lain.

\section{3) Analisis SWOT}

Analisis SWOT dilakukan untuk mengetahui tingkat kesiapan setiap fungsi dari keseluruhan fungsi madrasah yang diperlukan untuk mencapai sasaran yang telah ditentukan berhubungan dengan tingkat kesiapan fungsi ditentukan oleh tingkat kesiapan masing-masing faktor yang terlibat dalam setiap fungsi, maka analisis SWOT dilakukan terhadap seluruh faktor yang terlibat dalamsetiap fungsi, baik faktor yang tergolong internal maupun faktor yan tergolong eksternal. Sehubungan dengan analisis SWOT ini, peneliti melakukan wawancara dengan wakil kepala madrasah urusan humas: Sebelum program dirancang, terlebih dahulu dilakukan analisis SWOT untuk mengetahui kesiapan faktor-faktor yang ada..karena program yang direncanakan kira-kira efektif dan efisien tidak, baru kalau kita mengetaui program itu bisa dan 
memenuhi kebutuhan maka program tersebut dimasukkan.

\section{b. Pelaksanaan Peningkatan Mutu pendidikan}

Dalam pelaksanaan peningkatan mutu pendidikan di MTs Mafatihul Huda, ada beberapa program yang dibuat untuk meningkatkan mutu pendidikan, programprogram tersebut merupakan program unggulan yang ada di MTs Mafatihul Huda. Berbagai strategi telah disusun dalam berbagai silabus pembelajaran yang semua itu tercakup dalam program unggulan MTs Mafatihul Huda yang terdiri dari:

\section{1) Program Bidang Kurikulum}

a. Program Pembelajaran yang akomodatif

b. Team Teaching

c. Laporan Bulanan

d. Profesionalisme Guru

2) Program Bidang Kesiswaan

a) Pembinaan peningkatan bakat, minat, dan prestasi non akademik:

1) Literasi

2) Presenter dan MC

3) Drumband Band

4) Sepak Bola dan Futsal

5) Pencak Silat

6) Seni Suara

7) Kewirausahaan

8) Bola Basket

b) Pembinaan kedisiplinan dan akhlaq:

1) Upacara Bendera

2) Sebelum jam pelajaran pertama dilaksanakan maka seluruh siswa mengadakan kegiatan mengaji

3) Program Bidang Kehumasan:

1. Mengupayakan peningkatan partisipasi masyarakat terhadap MTs Mafatihul Huda

2. Mengupayakan adanya program pengabdian pada masyarakat

3. Membina hubungan dengan lembaga-lembaga pendidikan

4. Hubungan dengan Kelompok Kerja Madrasah (KKM)

5. Pendelegasian Guru dan Siswa dalam tugas tertentu, Seperti
Mengikuti Turnamen. Lomba, Seminar, dan lain-lain.

\section{4) Bidang Iman dan Takwa}

1. Shalat Dhuha Berjamaah

2. Kajian Al-Qur'an

3. Mendo'akan Orang Tua

4. Infaq Rutin

5. Ziarah Makam Waliyullah.

\section{c. Pengawasan Mutu Pendidikan}

Pengawasan merupakan proses pemantauan kegiatan untuk menjaga agar program pengawasan tetap terarah dan menuju kepada pencapaian tujuan yang direncanakan, serta mengadakan kontrol terhadap kegiatan-kegiatan yang menyimpang atau kurang tepat sasaran yang dituju. Sehubungan dengan hal itu, pengawasan menjadi fungsi penting dari keseluruhan fungsi manajemen dan merupakan fungsi penting bagi para pemimpin pendidikan, seperti kepala madrasah. Tujuan utama dari pengawasan adalah mengusahakan agar apa yang diprogramkan menjadi kenyataan, apabila proses pengawan dilakukan dengan baik maka penyimpangan atau kesalahan dapat dicegah atau setidak-tidaknya dapat diketahui sejak dini. Dari programprogram yang telah tersusun dalam upaya peningkatan mutu pendidikan, maka dalam proses pengawasan agar tetap berjalan sesuai dengan yang diprogramkan maka ada beberapa hal yang dilakukan madrasah.

Sehubungan dengan pelaksanaan pengawasan ini, berikut hasil wawancara peneliti dengan kepala madrasah: Dalam proses pengawasan pihak madrasah selalu mengadakan rapat evaluasi bersama staff dilaksanakan secara bersama, berkelanjutan secara berkala dalam periodik minimal tiga kali dalam satu tahun, dalam rapat itu dibahas semua persoalan-persoalan yang ada disamping juga mengevaluasi program yang sudah dan akan dilakukan

\section{Faktor Pendukung dan Penghambat dalam Implementasi Manajemen}




\section{Peningkatan Mutu Berbasis Madrasah \\ a. Faktor Pendukung}

Untuk dapat merealisasikan manajemen peningkatan mutu berbasis madrasah dengan baik dan sesuai dengan visi, misi madrasah maka secara tidak langsung madrasah memerlukan dukungan dari semua komponen yang ada, baik dari segi sumber daya manusia, sarana prasarana, dan juga orang tua, hal ini karena komponen yang ada dimadrasah harus saling mendukung untuk meningkatkan mutu pendidikan. Kebijakan manajemen peningkatan mutu berbasis madrasah merupakan sebuah inovasi baru terhadap proses pengembangan pendidikan, karena dengan ditetapkannya MPMBM, madrasah merasa lebih leluasa dan lebih mudah dalam melaksanakan kegiatan belajar mengajar dan dalam upaya peningkatan mutu pendidikan, karenanya madrasah diberi kebebasan untuk mengatur dan mengelola sumber daya yang ada dimadrasah dengan disesuaikan kondisi dan realitas masyarakat setempat.

Bersama dengan ini peneliti melakukan wawancara dengan kepala madrasah berkenaan dengan faktor pendukung dalam implementasi manajemen peningkatan mutu berbasis madrasah. dalam prakteknya manajemen peningkatan mutu berbasis madrasah ini faktor yang paling mendukung adalah solidnya semua komponen yang ada di madrasah, dengan semangat yang tinggi dari pendidik, Staff dan masyarakat ikut berperan serta dalam membangun madrasah.

Dalam hal ini peneliti juga melakukan wawancara dengan waka urusan humas menyebutkan: faktor pendukung dalam pelaksanaan manajemen peningkatan mutu berbasis madrasah adalah sumber daya madrasah, artinya unsur-unsur yang ada dimadrasah mendukung mulai dari staff sampai unsur lainnya mendukung, karena semua tahu bahwa peran madrasah lebih luas dan tidak lagi harus sama persis dengan yang ditetapkan oleh pusat.

Dari sini dapat dipahami bahwa faktor pendukung dalam mengaktualisasikan manajemen peningkatan mutu berbasis madrasah adalah kekompakan dan semangat juang yang tinggi dari elemen-elemen yang ada di madrasah mulai dari SDM, guru, karyawan, sarana prasarana guna lebih meningkatkan mutu pendidikan.

\section{b. Faktor Penghambat}

Faktor penghambat dalam pelaksanaan peningkatan mutu pendidikan di madrasah. Dari hasil observasi dan wawancara peneliti di lapangan menunjukkan bahwa dalam upaya peningkatan mutu pendidikan di MTs Mafatihul Huda ada beberapa faktor yang menghambat dalam upaya peningkatan mutu pendidikan sebagaimana hasil wawancara peneliti dengan kepala madrasah menyebutkan: kurangnya pemahaman masyarakat tentang pentingnya pendidikan bagi anak- anaknya merupakan salah satu dari beberapa faktor penghambat yang akan menjadi prioritas yang akan segera disosialisasikan. Dalam hal ini peneliti juga melakukan wawancara dengan wakil kepala kurikulum. faktor yang menghambat peningkatan mutu pendidikan di madrasah ini dari sebagian dari guru, program kerja yang sudah jadi, guru kadang lambat dalam mengeksekusi. Sedangkan waka humas menyebutkan berkenaan dengan faktor penghambat dalam mengaktualisasikan manajemen peningkatan mutu: Hambatan kita dalam upaya peningkatan mutu harus segera diatasi bersama sehingga ada perubahanperubahan yang terjadi di madrasah sehingga menciptakan madrasah yang unggul.

Untuk mengatasi faktor penghambat tersebut, MTs Mafatihul Huda melakukan langkah-langkah sebagai berikut:

1. Melaksanakan sosialisasi yang tujuannya untuk menanamkan pada siswa/orang tua/masyarakat tentang pentingnya pendidikan. 
2. Memberikan pembekalan kepada guru hal sebelum tahun ajaran baru dimulai. Intens dan berkelanjutan dalam mensosialisasikan program-kerja yang telah direncanakan, kemudian disosialisasikan oleh semua komponen madrasah.

\section{PENUTUP}

\section{A. Kesimpulan}

1. Salah satu konsep yang ditawarkan untuk meningkatkan potensi madrasah ialah dengan menerapkan Manajemen Peningkatan Mutu Berbasis Madrasah/Sekolah (MPMBM/S) atau yang lebih dikenal dengan Manajemen Pendidikan Sekolah (MPS). Sehingga setiap institusi pendidikan lebih leluasa dalam mengolah dan mengembangkan potensi yang dimiliki. Manajemen peningkatan mudu berbasis madrasah/sekolah merupakan alternative baru dalam pengelolaan pendidikan yang lebih menekankan pada kemandirian dan kreatifitas sekolah. Manajemen Peningkatan Mutu Berbasis Madrasah/Sekolah (MPMBM/S) dalam penelitian ini yaitu model manajemen yang memberikan otonomi lebih besar kepada sekolah dan mendorong sekolah untuk melakukan pengambilan keputusan secara partisipatif untuk memenuhi kebutuhan mutu sekolah atau untuk mencapai tujuan mutu sekolah dalam kerangka pendidikan nasional.

2. Dari hasil observasi yang dilakukan oleh peneliti di lapangan menunjukkan bahwa manajemen peningkatan mutu berbasis madrasah di MTs Mafatihul Huda sudah bagus, dimana ini didasarkan pada pengamatan peneliti terhadap kondisi dan realitas yang ada, begitu juga dengan hasil wawancara peneliti dengan kepala madrasah dan para wakil kepala madrasah yang menyampaikan bahwa manajemen peningkatan mutu berbasis madrasah sebagai kebijakan nasional yang dapat dilaksanakan.

3. Faktor Pendukung Dan Penghambat Dalam Mengimplementasikan Menajemen Peningkatan Mutu Pendidikan di MTs Mafatihul Huda

a. Faktor Pendukung

1) Dukungan dari berbagai elmen yang ada dimadrasah baik kepala sekolah, guru, karyawan, dan orang tua siswa

2) Sarana dan prasarana yang memadai

3) Kebijakan yang dikeluarkan oleh madrasah/sekolah sesuai dengan target dan sasaran.

b. Faktor Penghambat

1) Minimnya pemahaman masyarakat sekitar tentang pentingnya pendidikan bagi semua di masa mendatang

2) Pendidik lambat dalam melaksanakan program kerja yang telah direncanakan

3) Program-program yang telah direncanakan tidak dilaksanakan dengan baik oleh pihak madrasah.

\section{E. DAFTAR PUSTAKA}

Amri, Sofan. 2013. Peningkatan Mutu Pendidikan Sekolah Dasar dan Menengah. Jakarta: PT. Prestasi Pustaka Raya

Arikunto, Suharsimi dan Lia Yuliana. 2008. Manajemen Pendidikan. Yogyakarta: Aditya Media Yogyakarta

Bafadal, Ibrahim. 2006. Manajemen Peningkatan Mutu Sekolah Dasar. Jakarta: PT Bumi Aksara 
Danim, Sudarwan. 2007. Visi Baru Manajemen Sekolah. Jakarta: Bumi Aksara

Departemen Pendidikan Nasional. 2001. Manajemen Peningkatan Mutu Berbasis Sekolah, Buku 1 Konsep dan Pelaksanaan, Jakarta: Dirjen Dikdasme

Fadjar, Malik. 1998. Visi Pembaruan Pendidikan Islam. Jakarta: LP3NI

Mulyasa. 2002. Manajemen Berbasis Sekolah. Bandung: PT Remaja Rosdakarya

-2005. Menjadi Kepala Sekolah Profesional Dalam Konteks Menyukseskan MBS Dan KBK, Cet V .Bandung: PT. Remaja Rosda Karya

2007. Manajemen Berbasis

Sekolah: Konsep, Strategi dan Implementasi. Bandung: Remaja Rosda Karya

Mutohar, Prim Masrokan. 2013. Manajemen Mutu Sekolah. Jogjakarta: Ar-Ruzz Media

Nakosteen, Mehdi. 1996. Kontribusi Islam atas Dunia Intelektual Barat: Deskripsi Analisis Abad Keemasan Islam. Edisi Indonesia. Surabaya: Risalah Gusti: 1996

Nurkholis, 2003. Manajemen Berbasis Sekolah:Teori, Model, dan Aplikasi. Jakarta: PT.Grasindo

Prabowo, Listyo. 2008. Manajemen Pengembangan Mutu Sekolah/Madrasah. Malang: UIN Malang Press

Sallies, Edward. 2006. Total Quality Management In Education (alih bahasa Ahmad Ali Riyadi). Jogjakarta: IRCiSoD
Sumayang, Lalu. 2003. Manajemen produksi dan Operasi. Jakarta: Salemba Empat

Sunhaji. 2006. Manajemen Madrasah. Yogyakarta: Grafindo Litera Media

Umaedi. 1999. Manajemen Peningkatan Mutu Berbasis Sekolah, (Depdikbud, Direktorat Jendral Pendidikan Dasar dan Menengah, Direktorat Pendidikan Menengah Umum)

Zamroni. 2007. Meningkatkan Mutu Sekolah. Jakarta: PSAP Muhamadiyah

www.dikdasmen.depdiknas.go.id, Artikel pendidikan, Konsep Dasar Manajemen Peningkatan Mutu Berbasis Sekolah.

http://jurnalsdm.blogspot.com/2010/03/manajem en-peningkatan-mutu-berbasis.html

http://www.ssep.net/director.html

http://www.geocities.com/agus_lecturer/m anajemen/pengertian_manajemen.ht $\underline{\mathrm{m}}$ 